\title{
The Adaptation of Shakespeare's Hamlet in Different Cultural and Historical Contexts
}

\author{
Ziad Abushalha \\ School of Arts, Szeged University, PO Box 6722 Mosavai ut 20, Szeged, Hungary
}

\begin{abstract}
This study aims at examining why Shakespeare's Hamlet has been adapted and appropriated in different historical and cultural contexts. The study begins by introducing the reasons behind adapting this play and how the play's thematic variety and its deep tackling of controversial philosophical, social, political and human issues, that interest everyone from different cultures and times, are the reasons that made it transcultural. The study then tries to trace the journey of adapting Hamlet through history starting from the seventeenth century up to postmodern era. After that, it dwells on examples from different cultural contexts such as Europe, Asia and Africa, Canada and many other places to prove the play's universality. The study also includes many examples of cinematic, poetic and cartoony adaptations of the play to indicate the ability of the play to adjust itself to different artistic and cultural mediums.
\end{abstract}

Keywords: adaptations, appropriations, transculturalism

DOI: $10.7176 /$ JLLL/56-04

Publication date:May $31^{\text {st }} 2019$

\section{Introduction}

Hamlet, as a play more than character, is considered by T. S. Eliot as "a Mona Lisa of literature" (1932: 143). Part of the play's popularity is attained from Shakespeare's ability to dramatize the lives of men and women as they are on stage, and his skillfulness to tackle deep philosophical, social, political and human issues that interest everyone from different cultures and times. This study aims at examining how Shakespeare's Hamlet became transcultural through different adaptations and appropriations by writers from different historical and cultural contexts.

Hamlet's story, themes and structure have distinguished it not only from other Shakespearean works but from other theatrical performances, and perhaps no play in the English literature received all that much of attention, translation, and reworking more than Hamlet. The play showed a huge flexibility to conform to many cultures and histories and registered a huge ability to cross borders, cultures and times. It became transcontinental, multicultural and intermedial as Jan Kott indicates in his Shakespeare Our Contemporary:

No Dane of flesh and blood has been written about so extensively as Hamlet. Shakespeare's prince is certainly the best known representative of his nation. Innumerable glossaries and commentaries have grown round Hamlet, and he is one of the few literary heroes who live apart from the text, apart from the theatre. His name means something even to those who have never seen or read Shakespeare's play. In this respect he is rather like Leonardo's Mona Lisa. We know she is smiling even before we have seen the picture (1954: 58).

Long ago, writers, critics and philosophers frequently asked the question why Hamlet? The answer for this question is neither peculiar nor difficult. The play is simply a bricolage of many juxtapositions; love vs. hatred, war vs. peace, rationality vs. irrationality, loyalty vs. betrayal, appearance vs. reality, and determination vs. procrastination. It is also about love, revenge, tactic, friendship, alienation, and art. The play raises up philosophical, psychological and sociopolitical issues that every culture is concerned with.

Part of the play's prevalence in different geographical places, cultures and times is its deep penetration into the psychology of human being. It touches upon various psychological sides that every man might experience. As a matter of fact, the ability of Hamlet to oscillate between different dualities of feelings and reasons are quite enticing for scholars and audiences. He can be both: emotional and reasonable, determinant and hesitant, wise and mad, sarcastic and serious, offensive and considerate, and much more. This has made his character alluring but rather perplexing at the same time for those psychoanalysts who tried to interpret his madness and hesitance through a plentiful number of scholarly works. Goethe, for example, believed that the burden thrown on Hamlet's shoulders, particularly after the appearance of his father's ghost out of the blue to trouble him with more uncertainties is rather unbearable for any man. On the contrary, Freud's conception of Hamlet's madness is generally positioned within the Oedipus Rex. Hamlet lost the object of his sexual desires, his mother Gertrud, and as a result he became neurotic. His frequent procrastination is because he imagines himself as Claudius in that both of the characters are seeking to fulfill their sexual drives and both act accordingly. Freud believes that every time Hamlet comes to act and kill his uncle, he freezes as he imagines himself in the same position.

However, I find myself more inclined to Goethe's assumption than Freud's. While Freud tries to consider 
Hamlet's problem as something instinctual, I believe that Hamlet is a victim for the abrupt external forces which changed his life upside down. This perhaps what distinguishes him from other characters in other Shakespearean plays and whose downfalls are caused mainly by their own tragic flaws. Also, I believe that Hamlet's tragic end is more successful in raising pity and fear in the audiences; for everybody can be Hamlet, and Hamlet can be any one.

Another reason that explains why such a play received that applauds through history is the fact that Shakespeare raised up many existential and philosophical questions that everyone might ask. This is not eccentric, since Shakespeare himself was interested in philosophy (Raspa 2016: 3-4), but Hamlet in particular was given much space to speak more than all the characters in other plays. This could be justified by the assumption that Shakespeare's mind at the time of writing the play was loaded with many questions and ideas, so he decided to allow his hero more space to raise them. He problematized his character's life with many uncertainties and confusions just to bring to the surface the philosopher hidden in him. Hamlet shows a huge ability to comment on existential ideas: "how weary, stale, flat, and unprofitable seem to me all the uses of this world," to contemplate about man's nature: "what a piece of work is a man," to lament alienation "now I am alone. Oh, what a rogue and peasant slave am I," to theorize about the goodness vs. evil dichotomy: "for there is nothing either good or bad, but thinking makes it so," to speculate about confusion: "to be or not to be," and to contemplate about friendship and loyalty: "those friends thou hast, and their adoption tried, Grapple them unto thy soul". Other characters were able to philosophize and to theorize about different issues in life: Horatio comments on man's agony in "what is it you will see? If aught of woe or wonder, cease your search," the graves digger speaks about man's action "an act hath three branches - it is to act, to do, to perform," and Polonius gives social advice about life: "neither a borrower nor a lender be, For loan oft loses both itself and friend." As a matter of fact, all these philosophies, circulating in Shakespeare's play, make it a source where one might refer to when contemplating about different aspects of life.

Additionally, Hamlet exemplifies one of the everlasting struggles in life, the struggle between innocence and tyranny, fragility and power. It is about the illegitimate usurping of thrones that asks upon a revolutionary hero to 'put things right' in a corrupted stat. It is a mere dramatization of political struggle which might happen any time and in any place. This struggle occurs between kings, princes and other courtiers, considered at the top of the social hierarchy, who plot against one another for the sake of power and political supremacy. The struggle over power fulminates gradually throughout the play to include innocent victims- six main characters die in the play- and extends outside the court to ruin the whole state of Denmark. This political conflict which can actually be described as destructive and inclusive shifts the play from being a dramatization of a personal tragedy into a state tragedy. It is not only that, but it can be compared to other political conflicts happing worldwide any time.

Furthermore, Shakespeare's tackles one of the most controversial issues; i.e. the struggle against the patriarchal subjugating of women, but it is not very clear whether Shakespeare has a particular attitude against woman, or he tries to present the common perception of women in society at that time. Kathrin Köhler in Tragic Patriarchy: The Misogynist Side of Shakespeare in 'Hamlet' and Othello comments on the argument: "There are many critics [feminist critics] who see Shakespeare as the patriarchal Bard, and many who oppose this and think that his stand was well ahead of his time. All fins arguments in his works to support their view and the debate are going" (2004: 3).

Both arguments are possible, but what matters most in my opinion is the fact that the representation of women in Hamlet, as fragile and treacherous, always incited severe feminist criticism and many feminist critics had suggested that Shakespeare's play needs to be rewritten in a way that changes this intolerable conventional image of women. In Hamlet: A Critical Reader, both Ann Thompson and Neil Taylor give solution for this problem: "Perhaps the only way to redeem these characters [Ophelia and Gertrude] is to re-inscribe them in different fictions of their own" (2016: 10), and this in fact what some feminist writers have done. Take for example the Canadian Margret Clarke who readapted the play by replacing Hamlet's name with Gertrude and Ophelia in the title of her play, Gertrude and Ophelia. Clarke retells the same incidents of Shakespeare's play, but this time from Gertrud and Ophelia's perspectives aspiring to change the patriarchal perception of women as fragile figures deployed in different societies. Both Ophelia and Gertrude are portrayed in the play as strong and enough brave to argue openly about sexual freedom, lesbianism and women employment (Clark 1993).

\section{The Adaptation of Hamlet in Different Historical and Cultural Contexts}

The history of adapting and appropriating Hamlet goes back to the 18th century when the British David Garick took the risk and brought about huge alterations in his performance of Shakespeare's play. From these changes, he eliminated the death of Ophelia, the murder of Gertrud, the fence between Hamlet and Laertes, and the whole scene at the graveyard. Garick was criticized for omitting almost the five acts by many critics. In one of the comment on his performance, Charles Dibdin says: "All is written in a mean and trashy common place manner, and, in a word sullied the page of Shakespeare and disgraced the taste and judgment of Mr. Garrick" (2018: II.144), but Garrick confessed that he meant to do all these omissions. In one of his messages to Sir Willaim 
Young wrote: "It was the most imprudent thing I ever did in my life; but I had sworn I would not rest till I had rescued that noble play from all the rubbish of the fifth act" (cited in Garrick's Long Lost Alteration of Hamlet, 1934: 890-921). The play later was banned by publishers who disliked these changes.

Early-nineteenth century the play started to appear in nearby countries like German, France Russia and some other European countries. Thanks to the acting companies which toured around Europe at that time and thanks to the translators who introduced the play in different languages like François-Victor Hugo's professional translation in French, Georg Scheutz into Swedish, Michal Bosy into Slovakian, Oiveira Silva into Portuguese, and Heinrich Döring into German language. The play was also acted in USA, but most of the performances were replications for the original performance in Britain with slight differences. One of the performances that made slight changes to the original performance is Edwin Booth's productions of Hamlet in New York between 1860 and 1870 where he changed many things in the scenery and he was the first to drag the play to popular culture.

Hamlet, late nineteenth century and early twentieth century, began to expand to more geographical spots. The play became transcontinental and was taken by actors to Asia and Africa. Also, it has been relocated within modern theoretical frameworks and schools like psychoanalysis and formalism and reworked into various artistic genres and mediums like films. New adaptions were produced at that time such as Hamlet by the Russian Edward Craig and Konstantin Stanislavski in 1912. This appropriation is more into the stage of symbolism. New characters carrying the names of 'Death' and 'Madness' were added and who argued with other characters about abstract ideas (Garber 2012: 44). Another appropriation, but this time in China, is The Usurper of State Power by $\mathrm{Gu}$ Wuwei in 1916. The adaptation was a political mocking of the power abused by Yuan Shikai who struggled to restore the monarchy and to spoil the republic (Shashibiya 2003: 21). Hamlet is also reworked as a film around the mid-twentieth century by Lawrence Oliver. The film was in white and black and attained wide popularity since it was one of the first professional movies that tended to capture Shakespeare's play into this new medium of presentation. (Cookanew 2011: 23) In this film, many characters like Fortinbras, Guildenstern and Rosencrantz were not mentioned and many soliloquies and dialogues were omitted to suit the two-hour- time duration of the film.

In the second half of the twentieth century, particularly after the end of WWII, nihilism and meaninglessness prevailed worldwide and more particularly in Europe. Hamlet also participated in the scene through works like Tom Stoppard's Rosencrantz and Guildenstern Are Dead.to reflect on the disparity of that period. The two characters as mentioned previously rise up unanswerable existential questions that anyone might ask at that time. They participated in meaningless conversation and are ignorant of the importance of their existence in the world (Stoppard 1967). In the thirty years after the end of the war, the play relocated itself deeper in the political context, especially in the Central and Eastern part of Europe where most of the countries suffered under the communist regime. One of the playwrights who reworked the play in the political context is the Hungarian Geza Beremenyi in his adaptation, Halmi.

Suffering under the communist suppression after WWII, like other East European countries, Hungarians decided to foment anti-communist revolution in 1956 which was miserably failed as a result of the absence of the international support from other countries. A resorting to theatre and other artistic means was an indirect away to comment on the rather desperate scenes that followed the event. Here, Hamlet has reestablished itself like always to comment on the political issues in this geographical spot. The story takes place in Budapest, presented as a rather claustrophobic city made by the regime and which imprisons the characters in its semisuffocating atmosphere. Halmi, the main character, is delineated as hallow without much horizon of expectations for the future, and morally deteriorated like when he persuaded two of his classmates to rape Lili, his girlfriend and his teacher's daughter, the matter which makes her father commit suicide by throwing himself in front of a walking bus. Halmi also is in a permanent state of disappointment with his family, particularly after discovering his mother adulterous activity, and always in a state of anger with everyone. He is a copy of the young man the communist regime aspired to create in a climate full of defeatism, grotesque and absurdity (Orlich 2017: 115135). Similarly, from the other geographical places that reworked Hamlet for political purposes is the Arab world. In her book Hamlet's Arab Journey (2011), Margret Litvin comments on how the play was adapted by Arab playwrights in the second half of the twentieth century to comment of the political trauma they lived in under the tyrannical rulers. Plays such as Marzougi's Ismail/ Hamlet, Kazal al Majidi's Hamlet without Hamlet, Jawad Al Assdi's Forget Hamlet were all used to comment on those political problems prevalent at that time.

Moreover, in this period, the play has noticeably benefited from the theoretical discussion of the poststructuralist intertextuality. Playwrights, editors and filmmakers were granted more freedom to rework the play the way they want, and to add more artistic features after this assault on the post-Romantic idea of originality. Also, in the postmodern era, the play grasped new ways of dramaturgical techniques from the postmodern theatre. In 'Cinematographically Anatomy', the Hungarian Attila Kiss comments on one of the Hungarian postmodern experimental adaptations of Hamlet by the Hungarian Gabor Body. The stage is a real dramatization and intersection of Hamlet's brain where all characters acting in his mind. The stage is full of 
symbols that represent his brain's sells and veins. This adaptation utilized postmodern anatomical techniques in theatre to depict Hamlet's stream of consciousness (Kiss 2008: 4).

Other adaptations and appropriations were produced in the twenty-first century. The play is altered for many purposes like education. Hamlet Sou Eu, translated as 'I am Hamlet', is a Portuguese dramatic performance directed for children in 2007 as an educational means to introduce one of the English wide popular masterpieces to them. The play was staged at Teatro Maria Matos in Lisbon and many concrete objects were used on this stage to convey the story for the children. The play shows much interaction from the part of the children who participated in answering questions raised by the actors.

Adaptors also could not close their eyes on one of the important political revolutions happening nowadays in countries from the Middle East like Syria, Yemen, Tunis and Iraq. One of the adaptations which is used to comment on the political revolutions is Mahmoud Farouq's Goodbye Hamlet, an Arabic metadramatic performance performed by Egyptian university students in 2012. It shows the authors and the characters in searching of the suitable character that can play the role of Hamlet but each one they meet refuses to play the role without mentioning the reasons. The play had to be about Hamlet's father who was murdered by the supporters of the state leader, a representation of the Egyptian leader Hussney Mubarak at that time, and a character is urgently needed to revenge the old Hamlet. The play ends with no character found to play the role.

Culturally speaking, Shakespeare's play infiltrated in many cultural contexts and many nations considered Hamlet as their new savior prince. He is taken as a 'German Prince' by the German poet Ferdinand Freiligrath who announces "Deutschland ist Hamlet," translated as 'Germany is Hamlet' (Anthony 2002: 55), a Polish prince, and a Russian Prince as mentioned in The Thaw: Soviet Society and Culture during the 1950s and 1960s by Denis Kozlov\& Eleonory Gilburd (p.467). Other names such as Chinese Hamlet, Arab Hamlet, and Indian Hamlet all indicated how other nations and cultures envisioned and respected Shakespeare's character.

In Europe, Ruth J. Owen in The Hamlet Zone: Reworking Hamlet for European Cultures discusses how Hamlet was transported in the poetry, operas, theatres and movies produced by European editors, adapters and filmmakers. In his brief introduction, Owen points to the fact that the reworking of the play in Europe always had significant social, political and geographical causes in the back. In Hamlet Too Many produced in Portugal by the National Theatre in 2002, the author comments on the revolving gender-political debates around the role of women in Portugal. In the works of some Hungarian poets like Sándor PetĘfi's poem "Világosságot"translated as 'Light' - the play is used to evoke a sense of national identity, while in the Swedish Cristina Gottfridsson's Mohamlet (2006), the play was rewritten to foster multiculturalism. Another reason for adapting Hamlet in Spain, like Paulino Masip's The Dairy of Hamlet Garcia and Salvador de Madariaga's On Hamlet, is to motivate the Spanish intellectuals to take a positive side in the Spanish Civil War (1963-39). In Pap Hamlet by Arnoz Hols (1889), the play portrays German life at that time, while in Romania; the play is performed several times to comment on the censorship the socialist regime imposed on arts (Owen 2102).

In Asia, the play was most of the time associated with the political contexts. Many adaptations were discussed by Poonam Trivedi \&Minami Ryuta in Re-playing Shakespeare in Asia (2010). Most of the Asian countries produced adaptations and appropriations for the play. The Bad Sleep Well is a cinematic adaptation by the Japanese Akira Kurosawa (1960), Prince of the Himalayas is also a film produced by the Chinese Hu Xuehua, Haider is an Indian film by Vishal Bhardwaj (2014), and The Angel of Vengeance - The Female Hamlet is a Turkish drama film by Metin Erksan (1977). Other adaptations were by the Kuwaiti Sulayman Albassam under the title Alhamlit Summit, the Syrian Mamdouh Adwan's Hamlet Wakes Up Late and the Egyptian Mahmoud Farouq's Goodbye Hamlet (2012). In the American continent - most of the adaptations were produced by writers from USA such as Franco Zefferlie's film Hamlet, Paul Rudnick's play I Hate Hamlet (1991) and as a was produced by Walt Disney Feature's carton The Lion King (1994).

In Latin America, Margarida Gandara in her book Hamlet as a Figure of Thought In Latin America (2014) mentions some of the adaptations produced in countries from Latin America such as Hamlet by Argentina Luis Gregorich (1980), Um Certo Hamlet (translated as A Certain Hamlet) by the Brazilian Antonio Abujamra (1991), and Hamlet by the Mexican stage director Juan José Gurrola. She also indicates that play became an emblem for set of abstract ideas and political principles in these countries:

Like the rest of the modern, colonial and post-colonial world, Latin America has also seen its share of appropriations of Hamlet as a purported figure of thought that is, as an emblem for a set of ideas, problems and questions. Such appropriations, however, have usually come in less absolute, far-reaching and outspoken ways and shapes than the 19th century formula »Germany is Hamlet! (2014: 366)

Other country like Canada has its reproductions of Shakespeare's play. In Robert Gurik's Hamlet, prince du Québec (1986), the play reflects on the state of national awakening in the time of civil revolution in Québec. The play makes the question 'to be or not to be' as an emblem that will motivate people to take action in that revolution. In Australia, Mark Wilson's Anti- Hamlet is about Hamlet's psychological problems which were caused by the murdering of his father and the marriage of his mother.in this adaptations, another character was 
added with name 'Freud' to give Hamlet some advices on how to escape all these psychological issues (see Art Review at http://artsreview.com.au/anti-hamlet-2/).

In fact, the journey of Hamlet across-countries is bigger than that and it is much more enormous for one study to include. However, by mentioning the previous examples, I wanted to give general idea about why the play has received all that attention worldwide and what are the reasons that made playwrights, and filmmakers from different geographical places and cultural backgrounds want to reproduce the play.

\section{References}

Ar Armitage, D., Condren, C., \& Fitzmaurice, A. (2012). Shakespeare and early modern political thought. Cambridge, UK: Cambridge University Press.

Boal, A., Charles, A., McBride, M. L., \& Fryer, E. (2019). Theatre of the oppressed. London: Pluto Press.

Bradley, L. J. (2006). Brecht and political theatre: The Mother on stage. Oxford: Clarendon Press.

Calbi, M. (2016). Spectral Shakespeare: Media adaptations in the twenty-first century. Basingstoke: Palgrave Macmillan.

Cartelli, T. (n.d.). Repositioning Shakespeare: National Formations, Postcolonial Appropriations. Routledge.

Case, S., \& Reinelt, J. (1991). The performance of power: Theatrical discourse and politics. IA City, IA: University of Iowa Press.

Erven, E. V. (1992). The playful revolution: Theatre and liberation in Asia. Bloomington: Indiana University Press.

Hutcheon, L. (2014). Theory of Adaptation. Taylor and Francis.

Klein, H. M., \& Daphinoff, D. (1997). Hamlet on screen. Lewiston (N.Y.): The E. Mellen Press.

KOTT, J. (1990). Shakespeare Our Contemporary. Routledge. 